\title{
Malaria Kongenital di Daerah Endemis Indonesia: Studi di RSUD Dr. Tc Hillers Maumere Flores
}

Mario B. Nara, ${ }^{*}$ Irene Ratridewi Huwae, ${ }^{* *}$ Loeki Enggar Fitri, ${ }^{* * *}$ Natalia Erica Jahja, ${ }^{* *}$

${ }^{*}$ Departemen Ilmu Kesehatan Anak RSUD dr. TC. Hillers, ${ }^{* *}$ Departemen Ilmu Kesehatan Anak, ${ }^{* * *}$ Departemen Parasitologi Fakultas Kedokteran Universitas Brawijaya/ RSU dr. Saiful Anwar

Latar belakang. Di distrik Sumba Barat pada tahun 2004 dilaporkan malaria merupakan penyakit terbanyak. Era transportasi yang tinggi menyebabkan kemungkinan kejadian malaria kongenital di Lembata dan Flores (Maumere) juga tinggi

Tujuan. Memberikan gambaran mengenai malaria kongenital di RSUD dr. TC. Hillers, Maumere.

Metode: Penelitian deskriptif dilakukan mulai Desember 2012 - Desember 2013. Spesimen darah diambil dari neonatus dan ibunya, dikirim dengan dry ice ke Fakultas Kedokteran Universitas Brawijaya dan dilakukan pemeriksaan hapusan darah dan nested PCR.

Hasil. Angka kejadian malaria kongenital di RSUD dr. TC. Hillers Maumere selama 1 tahun penelitian 7,78\%. Dari 39 subjek yang terinfeksi malaria kongenital, 74,4\% terinfeksi P. vivax. Gejala neonatus yang terinfeksi antara lain, anemia (46,2\%), sepsis like $(28,2 \%)$, prematur $(38,5 \%)$, ikterus $(5,5 \%)$, dan asimtomatis $(48,7 \%)$.

Kesimpulan. Angka kejadian malaria kongenital di RSUD dr. TC. Hillers Maumere cukup tinggi dan dapat memberikan manifestasi klinis pada bayi yang dilahirkan. Sari Pediatri 2015;17(1):21-4.

Kata kunci: malaria kongenital, Plasmodium, Maumere, asimptomatis.

\section{Congenital Malaria in Indonesia's Endemic Areas: Study in Dr.T.C. Hillers Hospital Maumere}

Mario B. Nara,* Irene Ratridewi Huwae, ${ }^{* *}$ Loeki Enggar Fitri, ${ }^{* * *}$ Natalia Erica Jahja, ${ }^{* *}$

Background. At the district of West Sumba in 2004,malaria was reported the largest number of disease and in the era of high transportation, the likelihood of congenital malaria incidence in Lembata and Flores (Maumere) is also high

Objective. To provide an overview of congenital malaria in dr.TC. Hillers Hospital Maumere

Methods. Descriptive study was conducted from December 2012 - December 2013. Blood samples were taken both from the newborn babies and the mothers, shipped with dry ice to the Faculty of Medicine University of Brawijaya Malang and the examined by using blood smears and nested PCR.

Results. The incidences of congenital malaria in dr. TC.Hillers Hospital from 1-year study are $7.78 \%$. In this study, 39 subjects were infected with congenital malaria, $74.4 \%$ were infected with $P$. vivax. Symptoms of infected neonates include asymptomatic (48.7\%), anemia (46.2\%), sepsis like (28.2\%), prematurity (38.5\%) and jaundice $(5.5 \%)$.

Conclusion. The incidences of congenital malaria in dr. TC Hillers Hospital Maumere are quite high and can be manifested without symptoms in newborn babies.Sari Pediatri 2015;17(1):21-4.

Keywords : congenital malaria, Plasmodium, Maumere, asymtomatic, newborn

Alamat korespondensi: dr. Mario B. Nara, Sp.A. RSUD dr. TC. Hillers, Jalan Wairklau Maumere, Nusa Tenggara Timur 86111, Indonesia. Telepon+6281339008744. E-mail: mariobnara@yahoo.com 


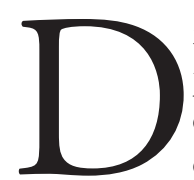
i dunia global, malaria tetap merupakan penyakit parasit yang serius pada manusia dan tercatat dengan insidens yang cukup tinggi. ${ }^{1}$ Pada tahun 2008, WHO memperkirakan terdapat 243 juta kasus malaria di Afrika Sub-Sahara, dengan $90 \%$ di antaranya disebabkan oleh Plasmodium falciparum dan 80\% kasus terjadi pada anak berusia kurang dari 5 tahun. $^{2}$ Indonesia merupakan daerah endemik malaria dan penyakit malaria masih merupakan penyakit infeksi utama terutama di kawasan Indonesia bagian Timur. ${ }^{3}$ Ibu hamil lebih rentan terhadap infeksi malaria, pada janinnya dapat terjadi malaria kongenital, abortus, persalinan premature, dan lahir mati. ${ }^{4}$

Di distrik Sumba Barat dari laporan yang tidak dipublikasikan pada tahun 2003 dilaporkan kira-kira 266.898 kasus malaria (klinis) dan 10.151 di antaranya positif dengan konfirmasi laboratorium $P$. falciparum dan P. vivax. Sementara itu, pada tahun 2004 dilaporkan malaria merupakan peringkat pertama dari 10 penyakit terbanyak dan bertanggung jawab terhadap mortalitas dan morbiditas di area tersebut. Dalam era transportasi yang tinggi maka tidak menutup kemungkinan kejadian malaria dan malaria kongenital di pulau-pulau lain juga tinggi termasuk di Lembata dan Flores (Maumere). ${ }^{5}$ Namun hingga saat ini data mengenai angka prevalensi malaria kongenital di Maumere belum tercatat dengan baik, sehingga sebuah penelitian untuk memberikan gambaran mengenai malaria kongenital di RSUD dr. TC. Hillers, Maumere.

\section{Metode}

Definisi malaria kongenital adalah infeksi malaria yang berasal dari transmisi parasit hidup dari ibu hamil ke janinnya dan parasit tersebut tetap ada setelah kelahiran, infeksi dapat terjadi prenatal atau selama persalinan. ${ }^{6}$ Bentuk aseksual dari parasit malaria ada di dalam darah tepi neonatus usia 1-7 hari tanpa memandang ada/ tidaknya gejala klinis. Diagnosis malaria kongenital ditegakkan dengan metode tetes tebal dan tetes tipis, kemudian dikonfirmasi dengan nested PCR. Penelitian dilakukan mulai Desember 2012 - Desember 2013 di RSUD dr. TC. Hillers Maumere. Spesimen darah diambil dari neonatus dan ibunya, kemudian dikirim dengan $d r y$ ice ke Fakultas Kedokteran Universitas Brawijaya dan dilakukan pemeriksaan apusan darah dan nested PCR.
Kriteria inklusi subjek penelitian adalah bayi berat lahir rendah (BBLR), dan ibu/keluarga setuju mengikuti penelitian dengan menandatangani surat persetujuan. Kriteria eksklusi yang diterapkan, antara lain 1) neonatus yang mengalami asfiksia, tersangka sepsis atau kelainan kongenital, 2) riwayat ketuban pecah dini lebih dari $18 \mathrm{jam}$, atau 3) proses persalinan yang traumatik. Besar subjek yang diperlukan dihitung berdasarkan analisis statistik komparatif dan didapatkan jumlah minimal sampel 64 pasang ibuneonatus. Analisis statistik dilakukan dengan program SPSS versi 17. Angka kejadian malaria kongenital disajikan dalam persentase. Penelitian ini telah disetujui Komite Etik Medik Penelitian Fakultas Kedokteran Universitas Brawijaya.

\section{Hasil}

Jumlah subjek yang diperoleh selama 1 tahun masa penelitian adalah 112 pasang bayi baru lahir dan ibu yang memenuhi kriteria inklusi. Setelah dilakukan seleksi data, didapatkan 92 pasang subjek dan 39 $(42,4 \%)$ subjek penelitian menderita malaria kongenital. Angka kejadian malaria kongenital di RSUD dr. TC. Hillers Maumere selama 1 tahun penelitian 7,78\%.

Sebuah penelitian pendahuluan di RSUD dr. TC Hillers, Maumere menunjukkan bahwa spesies malaria kongenital adalah $P$. falciparum dan $P$. vivax. ${ }^{7}$ Pada penelitian ini, dari 39 subjek penelitian yang terinfeksi malaria kongenital, $74,4 \%$ di antaranya terinfeksi $P$. vivax. Gambaran jenis Plasmodium penyebab malaria kongenital tertera pada Gambar 1.

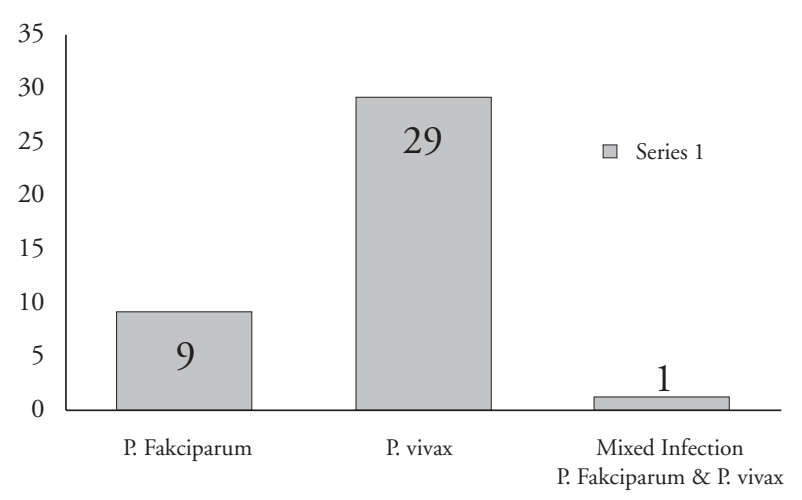

Gambar 1. Diagram batang spesies Plasmodium penyebab malaria kongenital di RSUD dr. TC Hillers, Maumere. 
Gambaran gejala neonatus yang menderita malaria kongenital, antara lain anemia $(46,2 \%)$, sepsis like $(28,2 \%)$, prematur $(38,5 \%)$ ikterus $(5,5 \%)$, dan asimtomatis $(48,7 \%)$.

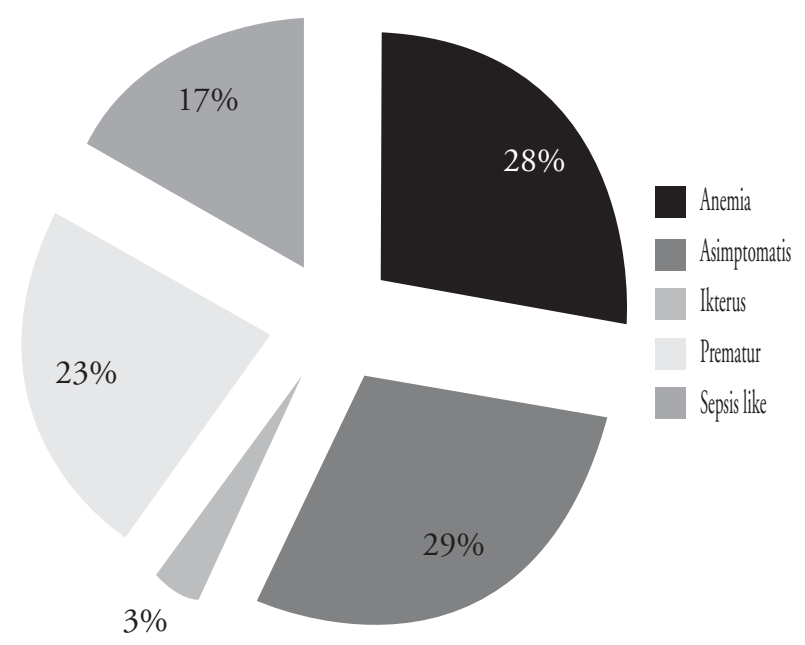

Gambar 2. Gejala klinis malaria kongenital pada neonatus di RSUD dr. TC Hillers, Maumere.

\section{Pembahasan}

Penelitian mengenai malaria kongenital pertama dilakukan di RSUD dr. TC Hillers, Maumere. Angka kejadian malaria kongenital selama satu tahun di RSUD dr. TC. Hillers, Maumere 7,78\%. Dari berbagai penelitian ditunjukkan angka kejadian malaria kongenital di daerah endemis bervariasi antara $0 \%$ 23\%. Variabilitas ini disebabkan oleh (i) kadar imunitas maternal; (ii) jenis spesimen darah yang digunakan (darah tepi atau darah plasenta); (iii) kemampuan analis medis; (iv) metode diagnostik yang digunakan; (v) gambaran perbedaan akibat faktor lingkungan, yang dapat dipengaruhi oleh tingkat transmisi malaria. ${ }^{8}$

Pada penelitian ini semua kasus malaria kongenital mempunyai berat badan lahir rendah, tetapi tidak berbeda bermakna dengan kelompok kontrol. Sebuah penelitian RCT di daerah endemis malaria, Mozambi, Afrika 9 yang mengikutsertakan 1030 ibu hamil menunjukkan bahwa infeksi malaria pada kehamilan berdampak pada peningkatan mortalitas dan morbiditas bayi baru lahir. Banyak studi mengenai hubungan malaria kongenital dengan outcome/luaran neonatus, tetapi belum sepenuhnya memberikan hasil yang konsisten. Penelitian pada tahun 1996-2001 di Yaonde, Kamerun, ${ }^{10}$ menunjukkan bahwa malaria plasenta akan menurunkan berat lahir bayi baru lahir 289 gram pada ibu primigravida dan 364 gram pada ibu yang berusia $<20$ tahun. Malaria mereduksi berat badan lahir (BBL) melalui kombinasi dampak sistemik dan lokal, yaitu melalui anemia yang diinduksi oleh malaria dan dampak dari infeksi plasenta. ${ }^{11,12}$ Parasit dapat secara langsung menyebabkan gangguan sirkulasi plasenta melalui penebalan dasar trofoblast yang luas dan peningkatan nekrosis fibrinoid serta penonjolan sitotrofoblast atau secara tidak langsung mengganggu fungsi plasenta dan/atau menginduksi lesi patologis. ${ }^{12,13}$ Pada penelitian ini, 23\% subjek malaria kongenital merupakan bayi prematur dan BBLR.

Hampir semua literatur yang membahas mengenai infeksi malaria di Afrika yang berkaitan dengan $P$. falciparum dan adanya infeksi tersebut akan memberikan dampak berupa kematian ibu, akumulasi parasit di plasenta, BBLR, infeksi malaria kongenital, anemia pada bayi, bahkan kematian bayi. Namun, di beberapa kawasan di Asia Tenggara termasuk Indonesia, jenis parasit yang dominan adalah $P$. vivax. ${ }^{4}$ Tidak banyak yang diketahui mengenai dampak sesungguhnya dari malaria kongenital pada kesehatan bayi. Parasitemia darah plasenta selain meningkatkan frekuensi insiden anemia pada usia beberapa bulan setelah kelahiran. ${ }^{14,15}$ Anemia fetal terjadi apabila kadar hemoglobin plasenta $<12,5 \mathrm{~g} / \mathrm{dL}$ dan prevalensi anemia fetal di Afrika Sub-Sahara sekitar 23,4\% - 97\%. ${ }^{12}$ Pada penelitian ini, jenis parasit yang dominan juga $P$. vivax dan kadar hemoglobin pada subjek penelitian yang menderita malaria kongenital juga lebih rendah.

Gejala dan tanda lain dari infeksi malaria kongenital yang mungkin terjadi, antara lain hepatomegali, ikterus, regurgitasi, tinja yang lembek, dan malas minum. Namun, gejala klinis malaria kongenital jarang ditemukan di Afrika Sub-Sahara, yang memiliki tingkat transmisi $P$. falciparum tertinggi di dunia. Hal tersebut menunjukkan meskipun parasit ditemukan pada plasenta ataupun darah neonatus, tetapi tidak selalu berhubungan dengan gejala penyakit. ${ }^{15}$ Salah satu faktor komorbid mortalitas dan morbiditas infeksi malaria kongenital adalah status imun ibu, yang ditentukan oleh paparan terhadap malaria sebelumnya. Infeksi yang terjadi dapat asimtomatik sehingga sering tidak terdeteksi tapi tetap berhubungan dengan parasitemia plasenta, yang akan memberikan dampak pada ibu dan janin. ${ }^{16}$ Pada penelitian ini didapatkan 
gejala tidak spesifik berupa ikterus, sepsis, persalinan premature, dan BBLR asimtomatis.

\section{Daftar pustaka}

1. WHO. Global health indicators in World health statistics 2011. France: WHO Press; 2011.h.79-88.

2. Crawley CJ, Mtove C, Nosten G, François. Malaria In Children. Lancet 2010; 375: 1468-81.

3. Tambajong EH. Patobiologi Malaria, Jakarta: EGC; 2000.

4. Singh N, Awadhia, SB, Dash AP, Shrivastava R. Malaria during pregnancy: a priority area for malaria research and control in South-East Asia. Regional Health Forum 2005;9:7-18.

5. Depkes RI. Kesehatan rumah tangga. Jakarta: Direktorat Binkesmas; 2001.

6. Carlier Y, Truyens C, Deloron P, Peyron F. Congenital parasitic infections: a review. Acta Tropica 2012;121:5570.

7. Jahja NE, Huwae IR, Nara, M B, Enggar LF. Abstract. Proceedings of the $6^{\text {th }}$ Annual Pediatrics Scientific Meeting. Solo, Indonesia. 2013;53:173.

8. Menendez C, Mayor Alfredo. Congenital malaria: the least known consequence of malaria in pregnancy. Seminars in Fetal and Neonatal Medicine 2007;12:20713.

9. Bardají A, Sigauque B, Sanz S, Maixenchs M, Ordi J, Aponte JJ, dkk. Impact of malaria at the end of pregnancy on infant mortality and morbidity. J Infect Dis 2011; 203:691-9.
10. Tako EA, Zhou Ainong, Lohoue Julienne, Leke Robert, Taylor Diane Wallace, Leke Rose. Risk factors for placental malaria and its effect on pregnancy outcome in Yaounde, Cameroon. Am J Trop Med and Hyg 2005;72:236-42.

11. Kassam SN, Nesbitt S, Hunt LP, Oster N, Soothhill P, Sergi C. Pregnancy outcomes in women with or without placental malaria infection. Inter J Gynaecol and Obst 2006; 93:225-32.

12. Uneke CJ. Impact of placental Plasmodium falciparum malaria on pregnancy and perinatal outcome in subSaharan Africa: II: effects of placental malaria on perinatal outcome; malaria and HIV. Yale J Biol Med 2007;80:95-103.

13. Menendez C, Ordi J, Ismail MR, Ventura PJ, Aponte JJ, Kahigwa E, dkk. The impact of placental malaria on gestational age and birth weight. J Infect Dis 2000;181:1740-5.

14. Ndyomugyenyi R, Magnussen P. Chloroquine prophylaxis, iron/folicacid supplementation or case management of malaria attacks in primigravidae in western uganda: effects on congenital malaria and infant haemoglobin concentrations. Ann Trop Med Parasitol 2000;94:75970.

15. Bardaji A, Sigauque B, Sanz S, Maixenchs M, Ordi $\mathrm{J}$, Aponte JJ, dkk. Impact of malaria at the end of pregnancy on infant mortality and morbidity. J Infect Dis 2011;203:691-9.

16. Sánchez PJ, Patterson JC, Ahmed A, penyunting. Toxoplasmosis, syphilis, malaria, and tuberculosis. Dalam: Avery's Diseases Of The Newborn. Edisi ke-9. Philadelpia: W.B. Saunders 2012.h.522-8. 